\title{
Plant species diversity and composition: experimental effects on marine epifaunal assemblages
}

\author{
John D. Parker*, J. Emmett Duffy, Robert J. Orth \\ College of William and Mary, School of Marine Science, Virginia Institute of Marine Science, PO Box 1346, Gloucester Point, \\ Virginia 23062, USA
}

\begin{abstract}
Plant diversity is believed to govern animal community structure, yet few studies have tested this relationship. We manipulated plant species diversity and composition (2 seagrasses and 3 seaweeds) and measured the abundance, diversity, and biomass of plant-associated macroinvertebrates in a temperate, estuarine seagrass community. Animal diversity was weakly but positively related to plant diversity (Simpson's $1-\lambda$ ). Most indices of animal diversity, however, were more strongly related to total plant surface area than to plant diversity. Epifaunal abundance and biomass increased, whereas epifaunal diversity and evenness decreased with total plant surface area. Both food and habitat covary with plant surface area, providing potential mechanistic explanations for these patterns. Plant species composition had strong effects on epifaunal community structure. After statistically controlling for effects of plant surface area, epifaunal abundance and biomass remained higher, and evenness remained lower, among assemblages composed of branched (mostly seaweeds) relative to unbranched (mostly seagrasses) macrophytes. Multiple regression analyses also revealed differential use of particular plant species by epifauna. For example, amphipods responded particularly strongly to the coarsely branched red alga Gracilaria verrucosa. Thus, our experimental results support a strong effect of plant species composition, and little effect of plant diversity per se, on the motile macrofauna that we studied. This conclusion is consistent with results of a concurrent field survey; epifaunal community structure differed among plant species and seasons, with no host-plant specialists. These results support evidence from both terrestrial and aquatic communities; ecosystem structural and functional properties are often more strongly influenced by particular attributes, rather than number of species, in a community.
\end{abstract}

KEY WORDS: Biodiversity $\cdot$ Community structure $\cdot$ Epifauna $\cdot$ Macroalgae $\cdot$ Zostera marina

\section{INTRODUCTION}

Recent experimental evidence, primarily from the terrestrial literature, suggests that plant species diversity and composition affect ecosystem processes, including nutrient cycling and biogeochemical fluxes, primary productivity, and resistance to drought and grazing (reviewed in Schläpfer \& Schmid 1999, Tilman 1999). Plant species diversity also influences associated animal communities because plants provide a

\footnotetext{
*Present address: Georgia Institute of Technology, School of Biology, Atlanta, Georgia 30332, USA.

E-mail: gte782w@prism.gatech.edu
}

variety of habitat, food and other resources (Lawton 1994). Indeed, the literature is replete with positive correlations between terrestrial animal and plant diversity (MacArthur \& MacArthur 1961, Pianka 1966, 1967, Murdoch et al. 1972, Willson 1974, Southwood et al. 1979). In grassland experiments, for example, plant diversity and productivity weakly but directly enhanced arthropod abundance and diversity, and indirectly affected arthropod parasites and predators (Siemann 1998, Siemann et al. 1998).

In contrast, correlations between animal and plant diversity have rarely been found in aquatic systems (Heck \& Wetstone 1977, but see Tonn \& Magnusson 1982). Rather, in marine seagrass beds, where this 
issue has received much attention, macroinvertebrate abundance and species richness are often correlated with plant biomass or surface area (Orth et al. 1984, Stoner \& Lewis 1985, Hall \& Bell 1988, Knowles \& Bell 1998). Although it is tempting to suggest that different rules apply to terrestrial and marine systems, it is noteworthy that the relationship between animal and plant diversity has only recently been tested in a terrestrial context, yet has apparently never been tested experimentally in marine systems. Given the intimate interactions between trophic levels (Lawton 1994), surprisingly few studies have addressed experimentally the influence of plant diversity on animal communities (Schläpfer \& Schmid 1999, but see Siemann et al. 1998, Symstad et al. 2000). Even fewer have addressed the functional role of diversity in marine benthic ecosystems (but see Paine 1992, Stachowicz et al. 1999, Duffy et al. 2001).

In this study, we experimentally tested the effects of plant species diversity and species composition on motile macroinvertebrate community structure, including abundance, diversity, evenness, and biomass, within a temperate estuarine seagrass community. To interpret our experimental results and elucidate natural host-plant use patterns, we also documented motile macrofaunal community structure on several plant species in the field over the course of $1 \mathrm{yr}$. Our goal was to assess the relative influences of plant species diversity and species composition on motile macrofaunal community structure in this system.

\section{MATERIALS AND METHODS}

Study site and organisms. We studied a seagrass meadow adjacent to the Goodwin Islands $\left(37^{\circ} 12^{\prime} \mathrm{N}\right.$, $76^{\circ} 23^{\prime} \mathrm{W}$ ) in the lower York River, a subestuary of Chesapeake Bay, Virginia, USA. Depth ranged from approximately 0.5 to $1.6 \mathrm{~m}$; temperature and salinity typically range from 4 to $30^{\circ} \mathrm{C}$ and 15 to $20 \mathrm{ppt}$, respectively. The study area is dominated by eelgrass Zostera marina, widgeongrass Ruppia maritima becomes abundant during summer, and drift macroalgae were found sporadically throughout the year. The most common drift algae encountered during the $1 \mathrm{yr}$ of observations were the coarsely branched red alga Gracilaria verrucosa, the foliose green alga Ulva sp., and the branched red algae Solieria filiformis and Ceramium rubrum (Table 1). Plants (i.e. vascular plants as well as seaweeds) are referred to hereafter by their genus names. The motile epifaunal community within Chesapeake Bay seagrass beds is relatively depauperate; fewer than 10 species of amphipods, isopods, and small gastropods typically comprise $>85 \%$ of motile macroepifauna (Marsh 1973, Parker 1998).
Table 1. Morphological classifications and estimated surface area to dry biomass ratios $\left(\mathrm{SA}: \mathrm{B}_{;} \pm 1 \mathrm{SE}\right.$ ) for seagrasses and seaweeds observed in this study. ${ }^{*}$ Plants used within diversity experiments

\begin{tabular}{|lcr|}
\hline Plant species & Morphology & SA:B $\left(\mathrm{cm}^{2} \mathrm{~g}^{-1}\right)$ \\
\hline Zostera marina* $^{*}$ & Unbranched & $429 \pm 15, \mathrm{~N}=11$ \\
Ruppia maritima $^{*}$ & Unbranched & $1851 \pm 314, \mathrm{~N}=6$ \\
Ulva sp. $^{*}$ & Intermediate & $1231 \pm 39, \mathrm{~N}=11$ \\
Gracilaria verrucosa* $^{*}$ & Branched & $1017 \pm 61, \mathrm{~N}=7$ \\
Solieria filiformis $_{\text {Ceramium rubrum }}^{*}$ & Branched & $755 \pm 79, \mathrm{~N}=5$ \\
& Branched & $2890 \pm 151, \mathrm{~N}=6$ \\
\hline
\end{tabular}

Sampling of phytal epifauna on seagrasses and drift algae. We used a lidded core tube $\left(0.40 \mathrm{~m}\right.$ long, $0.03 \mathrm{~m}^{2}$ area) to simultaneously collect epifauna and macrophytes. On 9 dates from August 1996 to August 1997 ( $\mathrm{N}=6$ per plant species on most dates) the tube was placed gently over monospecific algal clumps or seagrass patches and inserted into the sediment. A rubber stopper was inserted into the lid, enclosing the resident fauna, macrophytes, and approximately 5 to $10 \mathrm{~cm}$ of sediment. The core was removed and the contents were sieved through $1.0 \mathrm{~mm}$ mesh, placed into a plastic bag, and frozen until sorting. Depth and time were recorded at each sample location and standardized to depth at mean low water using the observed tidal variation. A 1-way analysis of variance (ANOVA) for each of the first 6 sample dates indicated that plant species were not distributed at different depths within this study area, so depth was not recorded thereafter. All motile epifauna retained in the field were enumerated and identified to species, and their abundances were standardized to total dry plant biomass (data not shown) and estimated total plant surface area (see 'Plant surface area determination' below) within each sample.

The aboveground biomass of each macrophyte species, and of macroscopic epiphytic algae (i.e. not microalgae), was determined in the laboratory. Samples were oven-dried at $60^{\circ} \mathrm{C}$ for a minimum of $48 \mathrm{~h}$. The abundance of macroscopic epiphytic algae was low throughout our study, averaging $0.91 \pm 0.24 \%$ (SE) of the total plant biomass per sample. Although care was taken to collect only the plant species being sampled, non-target plants were sometimes unavoidably collected. The average biomass of the target species (plus epiphytic algae) in each sample was $85.0 \pm 1.6 \%$ of the total plant biomass $(\mathrm{N}=139)$; there was generally more non-target material in the algal collections due to the presence of seagrasses beneath the drift macroalgae. Seagrass samples were generally less 'contaminated' with non-target material $(92.2 \pm 1.2 \%)$ than seaweed samples $(75.1 \pm 2.8 \%)$, on a per biomass basis. Because seagrass samples contained compara- 
tively fewer fauna per unit surface area than algal collections (see 'Results'), our estimates of fauna per unit surface area on seaweeds are likely to be conservative, assuming that algal collections also tended to include some portion of relatively low faunal density seagrass. Moreover, on an areal basis, extraneous material within seagrass and algal collections was more evenly distributed $(83.45 \pm 2.36$ and $77.58 \pm$ $2.65 \%$, respectively).

Experimental manipulations of plant diversity. To test whether plant diversity influences macro-epifaunal community structure (abundance, species diversity and composition, and biomass), we manipulated plant species richness in the field and measured motile epifaunal colonization after $6 \mathrm{~d}$. We selected treatment combinations to compare and contrast groups of plants with primarily simple, unbranched architecture (the seagrasses Zostera and Ruppia; both of which were unbranched and non-reproductive during the experiments), versus those with relatively complex, branched architecture (the seaweeds Gracilaria and Ceramium) (Table 2). Treatment combinations that contained both branched and unbranched plants, or those with the foliose alga Ulva, which can be structurally simple as a single sheet, or highly convoluted when many layers are stacked, are considered separately and referred to hereafter as 'intermediate'. Our treatments therefore ranged from 1 to 5 plant species, with varying plant species composition (grouped by plant architecture) at each of the lower levels of plant species richness.

We conducted 2 experiments, 10-16 and 17-23 June 1997 ( $\mathrm{N}=3$ each period), to increase replication. We created plant diversity gradients by transplanting cores of the 2 seagrasses and anchoring drift algae within treatment plots using stout aluminum wire. Plots were randomly selected, unvegetated areas of the same seagrass bed in which the seasonal survey was conducted. Each replicate plot consisted of plants placed within a circular patch $\left(0.139 \mathrm{~m}^{2}\right)$ identified with a labeled stake and buoy. We attempted to create each plant community with equal amounts of macrophyte coverage per plot via visual inspection, and to further offer equal amounts of individual plant species within multi-species assemblages. Although Zostera dominated the site during the experiments, other plants were also present, albeit not in great quantity, immediately adjacent to the experimental area. Zostera cores were collected from immediately outside the treatment plot with a core tube $\left(0.023 \mathrm{~m}^{2}\right)$ and planted into the bare area. Ruppia was not abundant immediately within the study area at the time and was collected from a nearby ( $25 \mathrm{~m}$ distant) inshore area. Seagrasses were gently shaken and scraped to remove attached and tube-dwelling animals. Drift algae were not sufficiently abundant immediately near our study site, and were collected from nearby James River less than $24 \mathrm{~h}$ before use and defaunated in a liquid insecticide solution (approx. $5 \%$ solution of Sevin ${ }^{\mathrm{TM}}$, active ingredient: $7 \%$ Carbaryl) less than $2 \mathrm{~h}$ before use. The insecticide solution does not affect growth or survival of several algal species (Carpenter 1986). Gross visual inspection indicated $100 \%$ mortality for motile macrofauna; and algae did not appear to senesce during the experiments.

We sampled the experimental plots after $6 \mathrm{~d}$. Motile epifaunal richness and abundance reach asymptotes on substrata placed in the field after approximately 1 wk (Stoner \& Lewis 1985, Virnstein \& Curran 1986), with approximately 30 to $40 \%$ daily turnover of phytal epifauna (Howard 1985, Edgar 1992, Taylor 1998). We collected our experimental plant assemblages by placing a weighted PVC cylinder $\left(82 \mathrm{~cm}\right.$ tall, $\left.0.139 \mathrm{~m}^{2}\right)$ that extended above the water surface around the treatments. All macrophytes were removed by hand and placed into a plastic bag. The interior of the cylinder was then dip-netted $(0.35 \mathrm{~mm}$ mesh) for five $30 \mathrm{~s}$ intervals. Two overlapping vinyl screens (each $1.0 \mathrm{~mm}$ mesh) were placed under the cylinder, and the entire apparatus was lifted above water level, sieving the entire interior. Sieve contents were then added to the sample bag. We also collected cores of natural, unma- 
nipulated Zostera and associated fauna using our lidded core on both collection dates. Other plants and associated fauna were not collected due to their absence from the immediate site locality at this time. Each experimental plant assemblage was treated identically, and we considered all animals retained on field sieves for further laboratory analyses.

Seagrasses, drift, and epiphytic macroalgae were sorted to species and dried (minimum $48 \mathrm{~h}$ ) at $60^{\circ} \mathrm{C}$. Animals (excluding sessile animals and annelids) were enumerated and sorted to species. Faunal abundance was standardized to estimated total plant surface area within each plot to compare treatments. Fauna generally regarded as infaunal (e.g. ampeliscid amphipods), or otherwise not associated with aboveground plants (e.g. pelagic fishes), were excluded from analyses.

Plant surface area determination. We used 2 general methods to estimate plant surface area. First, the surface area of blades of flat plants (Zostera and Ulva, $\mathrm{N}=$ 11 each) were determined by averaging 3 passes through a light-sensitive area meter (Li-Cor Model 3100). Secondly, we utilized a dye-coating technique (Hoegh-Guldberg 1988) to estimate the surface area of plants with 3-dimensional structure. Individual portions of plants were dipped into a surfactant-dye solution (0.4 g of Methylene Blue dye; 1\% Triton 10X detergent; $500 \mathrm{ml}$ deionized water) for $15 \mathrm{~s}$ and then spun 3 times in a salad spinner. Assuming that the dye solution coats each sample equally, the amount of dyesurfactant solution remaining on each plant should be directly proportional to plant surface area. We determined the amount of dye solution remaining by rinsing each sample thoroughly in $50 \mathrm{ml}$ of deionized water, and then measuring the spectral absorbance of the water-dye solution at $620 \mathrm{~nm}$. The plant sample was then dried at $60^{\circ} \mathrm{C}$ for a minimum of $48 \mathrm{~h}$ and weighed.

Absorbance and surface area (as measured with the light area meter) were highly correlated for samples of Zostera $\left(\mathrm{r}^{2}=0.89, \mathrm{p}<0.0001, \mathrm{df}=10\right)$ and Ulva $\left(\mathrm{r}^{2}=\right.$ 0.95, $\mathrm{p}<0.0001, \mathrm{df}=10$ ). The absorbance to surface area relationships for Zostera and Ulva were then used to estimate the surface areas of the seagrasses and seaweeds, respectively. We calculated surface area-tobiomass ratios (SA:B) after removing 4 gross outliers via Dixon's test (Sokal \& Rohlf 1995), and then used these ratios to convert plant biomass measured in field and experimental samples to estimated plant surface area (Table 1). Epiphytic macroalgal biomass (the abundance of which was extremely low throughout the study) was converted to surface area using the SA:B relationship for Ceramium, which has a morphology similar to most macro-epiphytic algae encountered in this study.

Although we recognize that plant species may differ in dye binding affinity, and thus influence the surface area estimates, we are unaware of more accurate or practical methodologies to assess the surface area of highly branched, 3-dimensional plants. Further, if we overestimated the surface area of highly branched plants due to capillary adhesion of dye between branch interstices, then our estimates of fauna per unit surface area on branching plants, which were typically higher than those on flat-bladed plants, are likely to be conservative. Additionally, when examining the results of regressions of faunal community metrics (abundance, diversity, evenness, and biomass) on total plant surface area (see 'Results'), there were similar trends both within and among plant species grouped by plant morphology, indicating that plant surface area was likely not grossly misrepresented among plant species.

Estimation of plant and animal diversity, and epifaunal biomass. Plant diversity within experimental treatments was estimated with the Simpson index, $1-\lambda$ (Lande 1996), using the proportional surface area as an abundance measure for each plant species. We present data standardized to plant surface area rather than dry plant biomass because the former is a more direct representation of plant abundance to phytal epifauna, particularly among plant species that differ widely in surface area to biomass ratios. Additionally, our conclusions are consistent with analyses of data standardized to dry plant biomass. Total animal diversity within each sample was estimated both as species richness and as the Simpson index $\left(1-\lambda=\Sigma p_{i}\left(1-p_{i}\right) \times\right.$ $(N / N-1)$; Lande 1996) where $p_{i}$ is the estimated species frequency in a random sample of $N$ individuals. Evenness was estimated with $E_{\text {var }}$ (Smith \& Wilson 1996) because of its sensitivity to both rare and abundant species. This feature is desirable when there are numerous rare but few dominant species. The Simpson index is a recommended diversity measure because it is relatively unbiased by sample size (Lande 1996).

We estimated animal biomass within the diversity experiments using a modified form of Edgar's (1990a,b) sieve-size method for benthic communities because faunal samples were preserved, thus preventing direct measurement of biomass via combustion. We used the equation $\Sigma n_{i} \times x_{i}$, where $n_{i}$ and $x_{i}$ are the abundance and mean estimated ash-free dry mass (AFDM), respectively, of animals, (broadly grouped into crustaceans and molluscs (Table III in Edgar 1990a) retained on sieve $i(5.6,4.0,2.8,2.0,1.4,1.0,0.71,0.50 \mathrm{~mm}$ mesh). Isopods were not accurately sorted by sieve size due to their slender morphology (J.D.P. unpubl. data). We measured isopods from rostrum to telson with a microscope and ocular micrometer and converted to AFDM using the following equations derived from Fredette et al. (1990), Erichsonella AFDM (mg) = $0.0056 L^{2.41}$, Edotea AFDM $(\mathrm{mg})=0.0046 L^{2.87}$, Idotea $\operatorname{AFDM}(\mathrm{mg})=0.0110 L^{2.17}$, where $L=$ length in $\mathrm{mm}$. 
Statistical analysis. We used simple linear regressions to test the influence of plant species diversity and total plant surface area (an index of plant abundance) on indices of epifaunal community structure, including abundance, biomass, species richness, evenness, and diversity. Data were pooled across both dates of the experiment because neither the date nor the date $\times$ treatment effect was significant in ANCOVA performed on these variables using plant surface area as a covariate (treatments were grouped according to plant species composition, see 'Results'). We also used ANCOVAs to test whether epifaunal community indices differed among treatments with dissimilar plant architecture (i.e. plant species composition) after controlling for the primary influence of total plant surface area. Variables were transformed (total abundance, evenness $=\log (100 x+1)$; biomass $=1 / x$; diversity $=x^{3}$ ) to satisfy Cochran's test for heteroscedasticity (Sokal \& Rohlf 1995).

Our experiment was designed to maintain approximately equal plant coverage across all treatments, yet the different plant species used differed in the amount of surface area per unit biomass. Thus, treatments differing in plant architecture (i.e. unbranched, intermediate, and branched) also tended to differ in the range of total plant surface area available to epifauna (see 'Results'). In an effort to distinguish the roles of individual plant species in producing patterns of epifaunal assemblage structure, we conducted 2 sets of multiple regression analyses. One tested the effects of individual plant species on aggregate epifaunal assemblage variables (abundance, biomass, species richness, even- ness, and diversity), and the other tested the effects of individual plant species on the abundance of the 3 most common epifaunal species. For each variable, we report the partial regression coefficient and its p-value, and then calculate the amount of variance each variable accounts for in the model as the difference in the overall $\mathrm{r}^{2}$ with and without that particular variable.

\section{RESULTS}

\section{Survey of motile phytal epifauna on seagrasses and drift algae}

A total of 11860 individuals representing 18 species was collected from the 6 different plant species listed in Table 1 during the survey of phytal epifauna (Table 3). While Zostera persisted throughout the year, other plant species in the study area were ephemeral, such that in some sampling periods one or more of those species were absent and could not be sampled. Drift algae were more common in fall and winter but relatively rare during other seasons. Gracilaria was the most common alga sampled and was present on all but 3 sampling dates.

Three epifaunal species, the isopod Erichsonella attenuata and the amphipods Cymadusa compta and Gammarus mucronatus, constituted almost $80 \%$ of the total animal collection pooled across dates, with 1 species, Erichsonella, accounting for over $44 \%$ of the total fauna collected (Table 3). Erichsonella peaked in abundance during late summer and fall, whereas

Table 3. Total abundance of all species collected during the survey and experimental portions of this study

\begin{tabular}{|c|c|c|c|c|c|}
\hline Survey & $\mathrm{N}$ & $\%$ of total & Experiments & $\mathrm{N}$ & $\%$ of total \\
\hline Erichsonella attenuata & 5242 & 44.20 & Gammarus mucronatus & 5287 & 53.77 \\
\hline Cymadusa compta & 3123 & 26.33 & Cymadusa compta & 2260 & 20.86 \\
\hline Gammarus mucronatus & 1083 & 9.13 & Erichsonella attenuata & 2123 & 19.59 \\
\hline Edotea triloba & 963 & 8.12 & Edotea triloba & 425 & 3.92 \\
\hline Elasmopus levis & 574 & 4.84 & Elasmopus levis & 61 & $<1$ \\
\hline Bittum varium & 354 & 2.98 & Palaemonetes pugio & 52 & $<1$ \\
\hline Ampithoe longimana & 145 & 1.22 & Bittum varium & 24 & $<1$ \\
\hline Palaemonetes pugio & 111 & $<1$ & Callinectus sapidus & 18 & $<1$ \\
\hline Callinectus sapidus & 91 & $<1$ & Palaemonetes vulgaris & 9 & $<1$ \\
\hline Hydrobia sp. & 51 & $<1$ & Caprella penantis & 8 & $<1$ \\
\hline Caprella penantis & 46 & $<1$ & Hydrobia sp. & 7 & $<1$ \\
\hline Palaemonetes vulgaris & 31 & $<1$ & Idotea baltica & 7 & $<1$ \\
\hline Unidentified xanthids & 19 & $<1$ & Mitrella lunata & 5 & $<1$ \\
\hline Paracaprella tenuis & 15 & $<1$ & Unidentified tanaid & 3 & $<1$ \\
\hline Palaemonetes intermedius & 5 & $<1$ & Unidentified gastropod & 2 & $<1$ \\
\hline Unidentified tanaid & 4 & $<1$ & Palaemonetes intermedius & 2 & $<1$ \\
\hline Dulichiella appendiculata & 2 & $<1$ & Ampithoe longimana & 1 & $<1$ \\
\hline \multirow[t]{2}{*}{ Mitrella lunata } & 1 & $<1$ & Eurypaneopus depressus & 1 & $<1$ \\
\hline & & & Paracaprella tenuis & 1 & $<1$ \\
\hline Total & 11860 & & & 10836 & \\
\hline
\end{tabular}




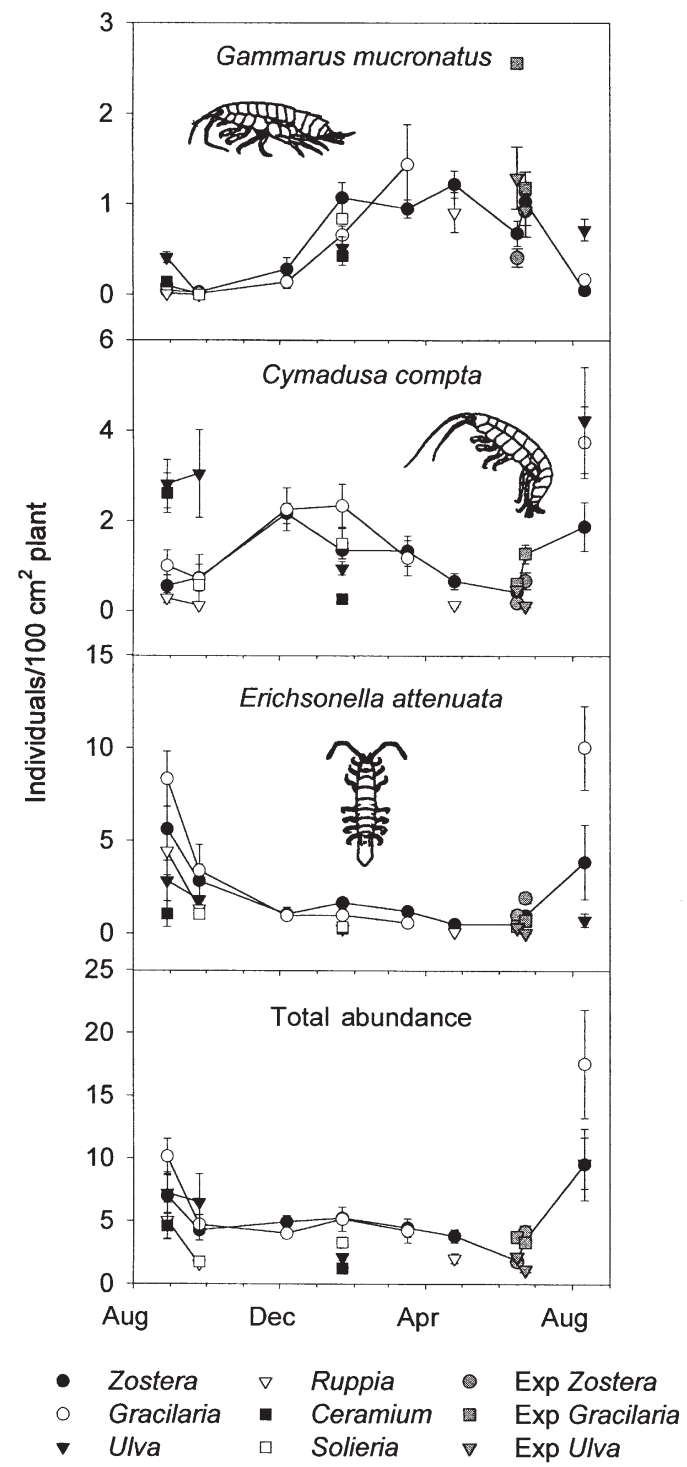

Fig. 1. Mean field densities ( $\pm 1 \mathrm{SE}$ ) normalized to plant surface area of the 3 most common epifaunal species collected during the field survey. Densities from experimental assemblages of Zostera, Gracilaria and Ulva shown for comparison

Table 4. Results of multiple regression analyses testing influence of individual plant species' surface areas on epifaunal abundance and biomass in the plant diversity experiments. $\mathrm{PRC}=$ partial regression coefficient. $\mathrm{p}<0.05$ in bold

\begin{tabular}{|c|c|c|c|c|c|c|}
\hline & \multicolumn{3}{|c|}{ Abundance } & \multicolumn{3}{|c|}{ Biomass } \\
\hline & PRC & $\mathrm{p}$ & $\begin{array}{l}\% \text { variance } \\
\text { accounted for }\end{array}$ & PRC & $\mathrm{p}$ & $\begin{array}{l}\% \text { variance } \\
\text { accounted for }\end{array}$ \\
\hline Zostera & 0.028 & 0.051 & 2.3 & 0.012 & 0.217 & 0.9 \\
\hline Ruppia & 0.047 & 0.062 & 1.4 & 0.014 & 0.428 & 0.2 \\
\hline Ulva & 0.019 & 0.000 & 14.4 & 0.012 & 0.000 & 14.4 \\
\hline Gracilaria & 0.037 & 0.000 & 47.6 & 0.024 & 0.000 & 50.6 \\
\hline Ceramium & 0.016 & 0.010 & 6.9 & 0.010 & 0.019 & 6.5 \\
\hline Overall $\mathrm{r}^{2}$ & 0.726 & & & 0.726 & & \\
\hline
\end{tabular}

Cymadusa peaked in the fall/winter, and Gammarus was most abundant during late spring/early summer (Fig. 1). None of the numerically dominant epifaunal species were restricted to a specific plant species, although there were differences in relative abundance of epifaunal species among plant species (Fig. 1). For example, Erichsonella was extremely abundant on Gracilaria in the fall of both years, but densities on Gracilaria differed relatively little from those on Zostera in winter/spring (Fig. 1). Additionally, Cymadusa was markedly abundant on the foliose green alga Ulva in late summer, but not so in the one winter collection or the experimental plot of this alga (Fig. 1). Patterns of animal relative abundance standardized to dry plant biomass differed from those when standardized to plant surface area, but there were still no clear cases of host-specificity. Epifaunal distribution differed erratically among plant species and dates.

\section{Experimental manipulations of plant diversity}

Our experimental treatments adequately created gradients in plant species diversity; nominal plant species richness in the experimental plots was positively correlated with observed species richness $\left(\mathrm{r}^{2}=0.36\right.$, $\mathrm{p}<0.0001$ ), and with plant species Simpson diversity $\left(\mathrm{r}^{2}=0.67, \mathrm{p}<0.0001\right)$. Total plant surface area was not related to plant diversity $\left(\mathrm{r}^{2}=0.00, \mathrm{p}=0.878\right)$. Additionally, our replicate plots averaged $95 \pm 2 \%$ (SE) of the intended plant species composition (biomass of intended plant species per biomass of extraneous species).

Plant species diversity only weakly influenced one measure of motile epifaunal community structure whereas plant surface area strongly affected nearly all measured indices. Epifaunal abundance and biomass in the experiment were unrelated to variation among plots in plant species diversity $\left(\mathrm{r}^{2} \leq 0.01, \mathrm{p} \geq 0.54\right.$ for both variables, Fig. 2), whereas the same epifaunal variables were strongly and significantly related to total plant surface area within the plots $\left(\mathrm{r}^{2} \geq 0.55, \mathrm{p}<\right.$ 0.0001 for both variables, Fig. 2). In contrast, epifaunal species richness was unrelated to either species diversity or surface area of plants within experimental plots $\left(r^{2}=0.04, p \geq 0.130\right.$ for both analyses, Fig. 3). Epifaunal evenness and species diversity (Simpson's $1-\lambda$ ) both significantly declined with increasing total plant surface area within plots $\left(\mathrm{r}^{2} \geq 0.21, \mathrm{p} \leq 0.0005\right.$ for each variable, Fig. 3). Epifaunal diversity was the only community variable 


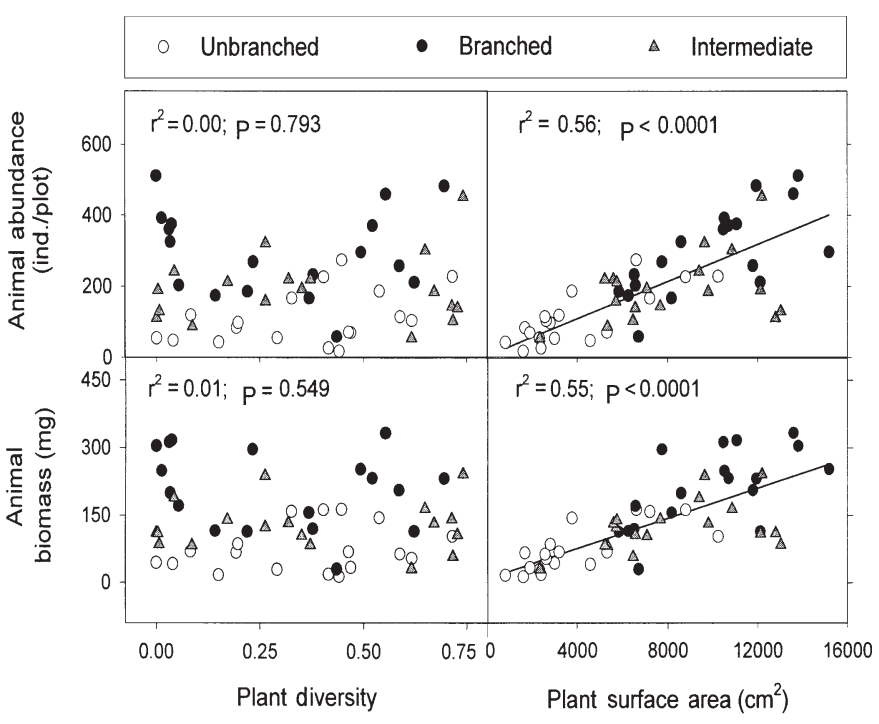

Fig. 2. Influence of plant species diversity (left-hand panels) and total surface area (right-hand panels) on the abundance and biomass of epifauna in the plant diversity experiments

measured that was significantly enhanced by plant diversity $\left(r^{2}=0.13, p=0.009\right.$, Fig. 3$)$.

Multiple regression analyses clarified the interactions between particular plant and animal species in producing the relationships demonstrated between plant and motile epifaunal assemblage variables. Overall, algae had stronger impacts on epifaunal communities than did seagrasses. Abundance of the 3 seaweeds used in the experiment significantly enhanced epifaunal abundance and biomass (Table 4). In fact, abundance of a single species, the branched red alga Gracilaria, accounted for roughly $50 \%$ of the variance in epifaunal abundance and biomass (Table 4). Epifaunal diversity-related variables were significantly influenced by algal abundance, not by seagrass abundance (Table 5). Among the 5 manipulated plant species, only Gracilaria significantly (positively) affected epifaunal

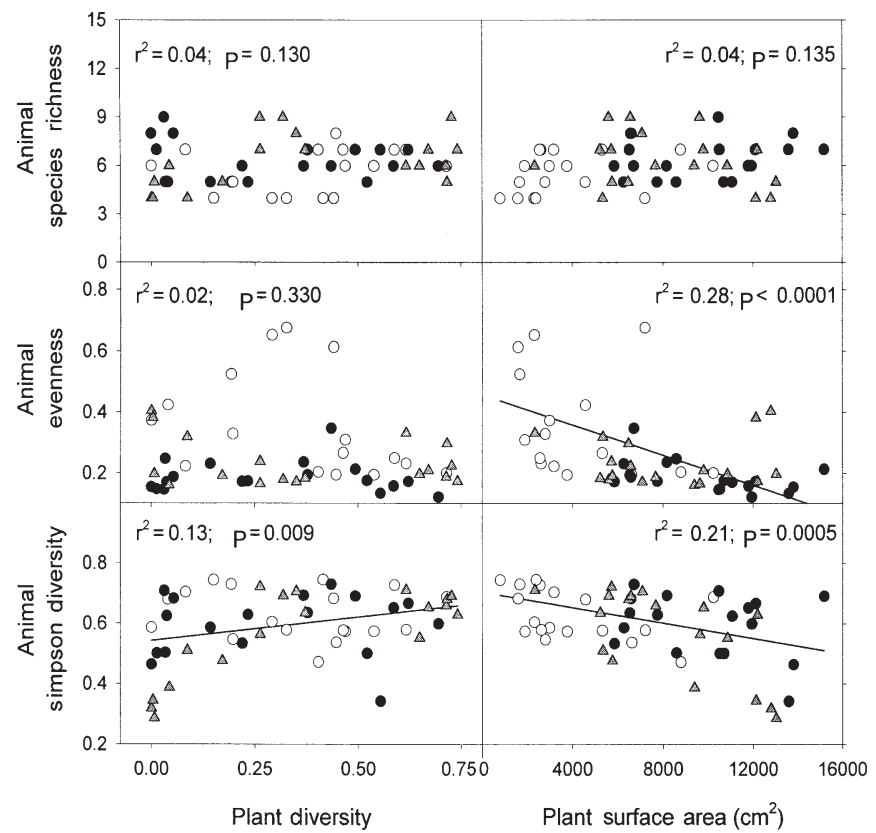

Fig. 3. Influence of plant species diversity (left-hand panels) and total surface area (right-hand panels) on the species richness, evenness, and diversity of epifauna in the plant diversity experiments. Symbols as in Fig. 2

species richness, presumably as an indirect consequence of its strong enhancement of epifaunal abundance (Table 4). Gracilaria and Ulva significantly reduced epifaunal evenness, although only Ulva significantly diminished Simpson diversity (Table 5). Curiously, although Gracilaria significantly influenced both epifaunal richness (positively) and evenness (negatively), it had no influence on epifaunal diversity (Table 5), possibly because its conflicting effects on epifaunal community structure were obscured in the Simpson diversity metric.

Although we found (as expected) no strict host specialization among the epifauna in this study (Fig. 1), epifaunal species responded differentially to particular

Table 5. Results of multiple regression analyses testing influence of individual plant species' surface areas on the epifaunal species richness, evenness, and diversity in experimental diversity plots. PRC $=$ partial regression coefficient, exponents in parentheses. $\mathrm{p}<0.05$ in bold

\begin{tabular}{|c|c|c|c|c|c|c|c|c|c|}
\hline & \multicolumn{3}{|c|}{ Richness } & \multicolumn{3}{|c|}{ Evenness } & \multicolumn{3}{|c|}{ Diversity } \\
\hline & $\begin{array}{c}\text { PRC } \\
\left(10^{-4}\right)\end{array}$ & $\mathrm{p}$ & $\begin{array}{l}\% \text { variance } \\
\text { accounted for }\end{array}$ & $\begin{array}{c}\text { PRC } \\
\left(10^{-5}\right)\end{array}$ & $\mathrm{p}$ & $\begin{array}{l}\% \text { variance } \\
\text { accounted for }\end{array}$ & $\begin{array}{l}\text { PRC } \\
\left(10^{-5}\right)\end{array}$ & $\mathrm{p}$ & $\begin{array}{l}\% \text { variance } \\
\text { accounted for }\end{array}$ \\
\hline Zostera & 3.07 & 0.257 & 2.1 & -2.54 & 0.418 & 0.9 & 0.597 & 0.710 & 0.1 \\
\hline Ruppia & 7.56 & 0.111 & 3.3 & -7.14 & 0.193 & 1.9 & 3.73 & 0.185 & 1.5 \\
\hline Ulva & 0.504 & 0.939 & 1.3 & -1.92 & 0.015 & 7.2 & -2.41 & 0.000 & 54.3 \\
\hline Gracilaria & 22.9 & 0.004 & 14.9 & -3.72 & 0.000 & 22.0 & -0.624 & 0.171 & 0.0 \\
\hline Ceramium & 1.43 & 0.219 & 3.0 & -1.83 & 0.177 & 4.1 & 1.37 & 0.052 & 2.7 \\
\hline Overall $r^{2}$ & 0.246 & & & 0.352 & & & 0.586 & & \\
\hline
\end{tabular}




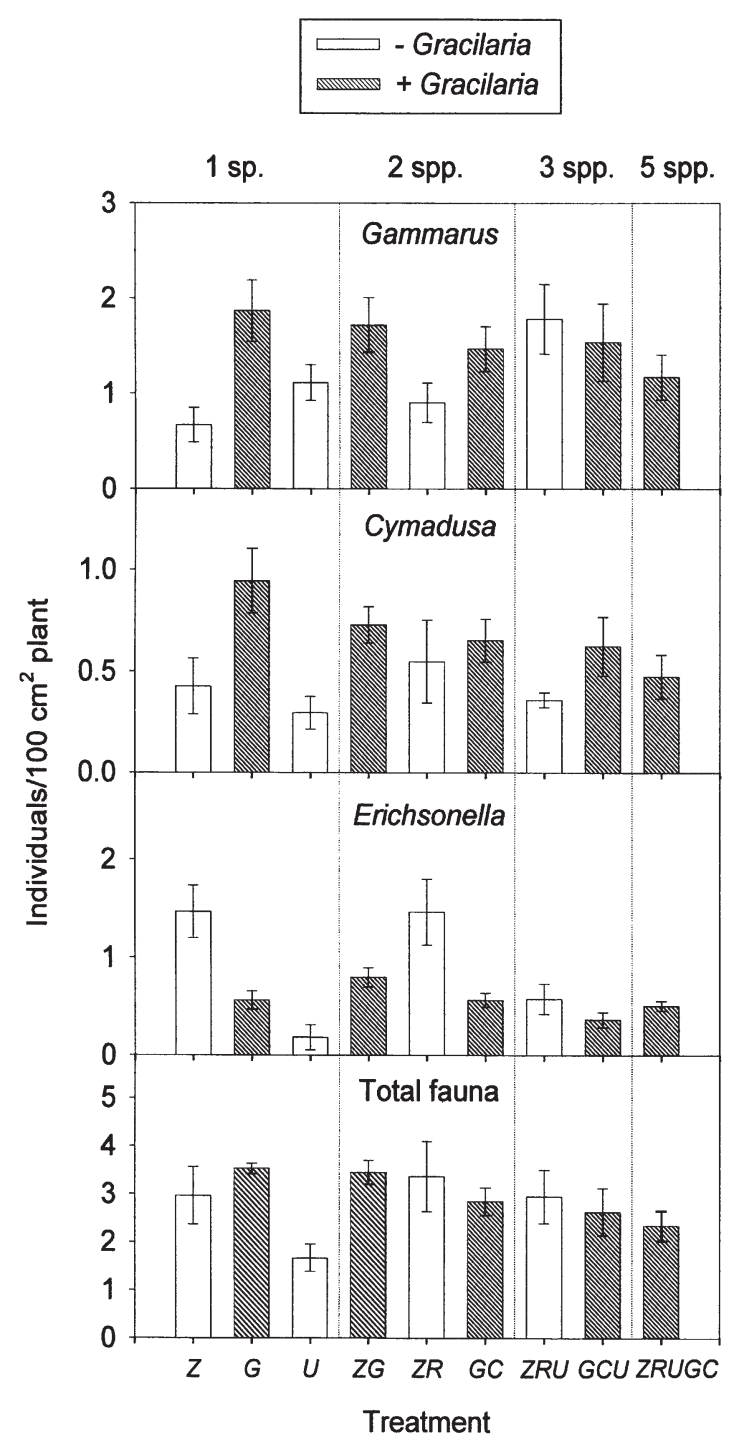

Fig. 4. Mean density $( \pm 1 \mathrm{SE})$ of the 3 most common epifaunal species and of total fauna for experimental treatments on both dates combined ( $\mathrm{N}=3$ each date) for treatments that contained the branched red alga Gracilaria and those that did not (see Table 2 for treatment abbreviations)

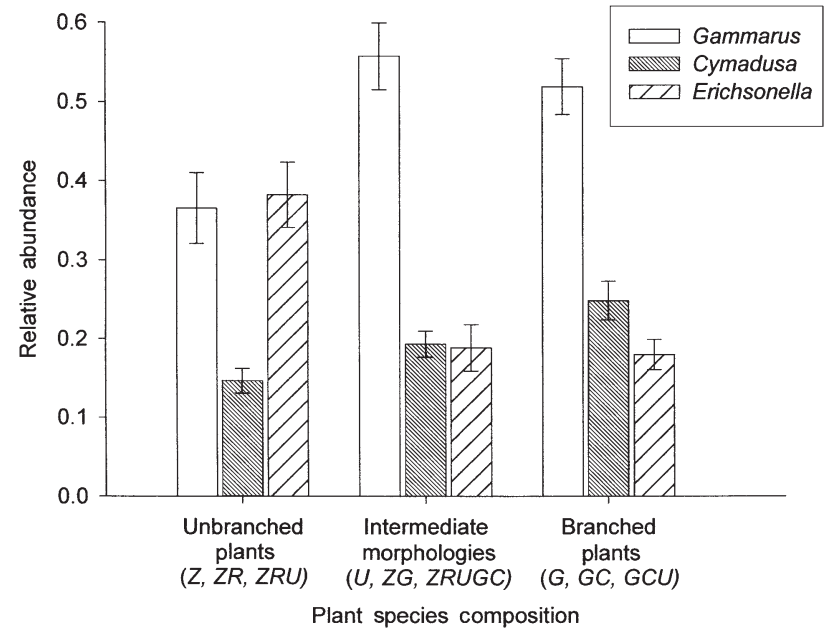

Fig. 5. Mean relative abundance $( \pm 1 \mathrm{SE})$ of the 3 most common epifaunal species in the plant diversity manipulation experiments as a function of plant morphology. Data are pooled across dates and by treatments as shown (see Table 2)

plants in the experimental plant assemblages (Fig. 4, Table 6). For example, Erichsonella was the only one of the 3 top epifaunal taxa significantly affected by seagrasses, showing positive responses to both Zostera and, to a lesser extent, Ruppia. Nevertheless, Erichsonella's abundance was still more strongly affected by Gracilaria and Ceramium. The abundance of all 3 algal species enhanced the abundance of the amphipod Cymadusa. The amphipod Gammarus responded positively to the seaweeds Gracilaria and Ulva. Gracilaria had a stronger effect on all 3 epifaunal species than did any other plant species. The stronger response to seagrasses of Erichsonella versus the amphipods (Fig. 4) resulted in a more even distribution of epifaunal species in the treatments composed of unbranched plants than in the branched treatments (Fig. 5).

When the strong influence of total plant surface area within a plot was controlled using ANCOVA, plant species composition (i.e. treatments grouping together unbranched, intermediate, and branched plants) still

Table 6. Results of multiple regression analyses testing influence of individual plant species' surface areas on variance in abundance of the 3 most common epifaunal species. PRC $=$ partial regression coefficient. $\mathrm{p}<0.05$ in bold

\begin{tabular}{|c|c|c|c|c|c|c|c|c|c|}
\hline & \multicolumn{3}{|c|}{ Gammarus mucronatus } & \multicolumn{3}{|c|}{ Cymadusa compta } & \multicolumn{3}{|c|}{ Erichsonella attenuata } \\
\hline & PRC & $\mathrm{p}$ & $\begin{array}{l}\% \text { variance } \\
\text { accounted for }\end{array}$ & PRC & $\mathrm{p}$ & $\begin{array}{l}\% \text { variance } \\
\text { accounted for }\end{array}$ & PRC & $\mathrm{p}$ & $\begin{array}{l}\% \text { variance } \\
\text { accounted for }\end{array}$ \\
\hline Zostera & 0.013 & 0.259 & 1.0 & 0.002 & 0.635 & 0.2 & 0.010 & 0.004 & 8.4 \\
\hline Ruppia & 0.020 & 0.326 & 4.7 & 0.009 & 0.284 & 0.8 & 0.013 & 0.022 & 3.1 \\
\hline Ulva & 0.016 & 0.000 & 9.1 & 0.002 & 0.045 & 3.3 & -0.0002 & 0.755 & 6.9 \\
\hline Gracilaria & 0.022 & 0.000 & 46.0 & 0.009 & 0.000 & 47.0 & 0.004 & 0.000 & 19.3 \\
\hline Ceramium & 0.004 & 0.458 & 1.5 & 0.006 & 0.008 & 10.4 & 0.006 & 0.000 & 19.0 \\
\hline Overall $\mathrm{r}^{2}$ & 0.623 & & & 0.617 & & & 0.567 & & \\
\hline
\end{tabular}


Table 7. Results of ANCOVAs testing effects of plant species composition (i.e. branched, intermediate, and unbranched plants grouped together), and date of the experiment on epifaunal abundance, biomass, richness, evenness, and species diversity in the diversity experiments. Total plant surface area within each plot was the covariate. Degrees of freedom are in parentheses. $\mathrm{p}<0.05$ in bold

\begin{tabular}{|c|c|c|c|c|c|c|c|c|c|c|}
\hline \multirow[t]{2}{*}{ Factors } & \multicolumn{2}{|c|}{ Abundance } & \multicolumn{2}{|c|}{ Biomass } & \multicolumn{2}{|c|}{ Richness } & \multicolumn{2}{|c|}{ Evenness } & \multicolumn{2}{|c|}{ Diversity } \\
\hline & MS & $\mathrm{p}$ & MS & $\mathrm{p}$ & MS & $\mathrm{p}$ & MS & $\mathrm{p}$ & MS & $\mathrm{p}$ \\
\hline Surface area $(\mathrm{cov})_{(1)}$ & 4.20 & 0.0001 & 0.002 & 0.0001 & 0.51 & 0.6226 & 0.48 & 0.0632 & 0.07 & 0.0034 \\
\hline Species composition $_{(2)}$ & 0.76 & 0.0472 & 0.0004 & 0.026 & 2.66 & 0.2904 & 0.52 & 0.0263 & 0.002 & 0.8108 \\
\hline Date $_{(1)}$ & 0.19 & 0.3694 & 0.0001 & 0.340 & 0.55 & 0.6094 & 0.03 & 0.6219 & 0.002 & 0.6303 \\
\hline Date $\times$ Species composition $_{(2)}$ & 0.02 & 0.9151 & 0.00001 & 0.899 & 0.64 & 0.7368 & 0.02 & 0.8316 & 0.015 & 0.1471 \\
\hline Surface area $\times$ Species composition $(2)$ & 0.60 & 0.0880 & 0.0005 & 0.022 & 2.28 & 0.3454 & 0.25 & 0.1586 & 0.001 & 0.9105 \\
\hline Surface area $\times$ Date $_{(1)}$ & 0.04 & 0.6940 & 0.0001 & 0.280 & 0.56 & 0.6063 & 0.48 & 0.5950 & 0.008 & 0.3054 \\
\hline Error $_{(44)}$ & 0.23 & - & 0.0001 & - & 2.09 & - & 0.13 & - & 0.007 & - \\
\hline
\end{tabular}

significantly influenced epifaunal abundance, biomass, and evenness (Table 7). This appears due to slightly higher mean epifaunal abundance and biomass, at a given level of plant surface area, in treatments composed of branched plants than in those composed of unbranched plants (Fig. 2). Interestingly, there is a significant interaction between plant surface area and plant species composition for the ANCOVA on epifaunal biomass (Table 7), again showing that the effect of plant surface area on epifaunal communities was not equal across plant species.

\section{DISCUSSION}

\section{Mechanistic bases of plant-animal association}

Upon first inspection, most of the effects of plant assemblage variation on animal communities in our study appear reducible to the responses of epifauna to variation in total plant surface area. Epifaunal abundance, biomass, diversity, and evenness were all strongly related to plant surface area. Most of the seaweeds in this study had higher ratios of surface area to biomass and all are more structurally complex than the seagrass Zostera marina (the seagrass Ruppia maritima, though structurally simple, has a relatively high SA:B ratio due to its narrow leaves, Table 1). After controlling for total plant surface area, however, there were still significant impacts of plant species composition (i.e. treatments contrasting plant architecture) on animal abundance, biomass, and evenness (Table 7), suggesting that qualitative aspects of plant identity also played a role in epifaunal community structure. Similarly, despite the lack of strict host specialization by epifauna encountered in this study, there were nonetheless strong, albeit inconsistent, differences among plant species in the abundance of particular epifaunal species on several dates in the field (Fig. 1).
A likely mechanism by which plant effects might influence associated animal assemblages is through provision of complex habitats. Species diversity is correlated with habitat complexity in a variety of systems (Kohn 1967, Abele 1974, Dean \& Connell 1987a,b,c, Kotler \& Brown 1988, Orth 1992 and references therein), and increased epifaunal densities are often correlated with the presence of seaweeds in many marine seagrass meadows (Stoner 1985, Stoner \& Lewis 1985, Schneider \& Mann 1991a, Holmquist 1997, Knowles \& Bell 1998). In our study, abundance of the amphipods Gammarus mucronatus and Cymadusa compta, and the isopod Erichsonella attenuata were significantly related to the abundance of Gracilaria (Table 6), which is a branched, structurally complex plant. Many amphipods are thigmotactic (Olyslager \& Williams 1993), remaining in almost constant contact with surfaces, and associate preferentially with microhabitats that closely match their body size (Edgar 1983a, Hacker \& Steneck 1990). Thus, greater abundance of epifauna on seaweeds might reflect responses to structurally complex plants.

However, testing the role of habitat complexity rigorously is difficult because of the lack of a widely accepted, objective measure of habitat complexity. Branched plants seem intuitively to be more complex than unbranched plants, but it is not clear whether their support of greater epifaunal abundance is due to greater complexity per se, or simply to greater relative surface area. In other words, the positive effects of plant surface area on epifaunal density may result from enhanced structural complexity, microalgal food availability or habitat. Our experiments did not distinguish among these possibilities, but field and laboratory experiments suggest that mobile epifauna are limited broadly by the abundance and productivity of periphyton, which in turn are often space-limited (Edgar 1991, Edgar \& Aoki 1993, Duffy \& Harvilicz 2001). Limited evidence indicates that Gammarus mucronatus, the most common epifaunal taxon in the 
experiments, is a generalized grazer of periphyton (Fredette \& Diaz 1986, Cruz-Rivera \& Hay 2000), and we suspect the other most common taxa are generalized grazers as well. However, in other systems, or among individual taxa, epifauna appear to be strongly affected by predation (Leber 1985, Hay et al. 1987, Holmlund et al. 1990, Duffy \& Hay 1991, 1994, Boström \& Mattila 1999), which can be reduced through the same aspects of habitat complexity (i.e. increased surface area) that fosters epiphyte production. This linkage between food and habitat makes it difficult to generalize between proximate and ultimate hypotheses for differential distribution of epifauna among morphologically disparate plants (e.g. Edgar 1983b,c,d, Bell \& Westoby 1986, Schneider \& Mann 1991b, Edgar \& Robertson 1992, Bologna \& Heck 1999). In our study, although there were strong impacts of plant surface area (Figs $2 \& 3$, Table 7), there were also clear differences among plant species (Figs $4 \& 5$, Tables $6 \& 7$ ), such that neither plant surface area nor plant morphology alone were adequate predictors of epifaunal community patterns.

A primary theoretical rationale proposed for effects of diversity on community organization involves niche complementarity among species, leading to more efficient resource use in a diverse assemblage (Tilman et al. 1997, Hooper 1998, Loreau 1998, Tilman 1999). By analogy, plant diversity could enhance animal diversity if animals are commonly host-specific. We found no evidence of consistent host-plant specialization in the fauna encountered in this study, presumably because few marine epifauna live and feed directly on host tissues (Lubchenco \& Gaines 1981, Hay 1992). Surprisingly, although many terrestrial arthropods do live, feed, and oviposit directly on or within their hosts (Strong et al. 1984), experiments conducted in a terrestrial grassland confirmed a weak relationship between plant and animal diversity (Siemann 1998, Siemann et al. 1998, Symstad et al. 2000).

\section{Plant diversity, species composition, and animal assemblage structure}

Most previous experimental studies on the functional effects of species diversity have concentrated on processes mediated by terrestrial plants, such as production, nutrient cycling, and drought resistance (reviewed in Schläpfer \& Schmid 1999, Tilman 1999). We aimed to extend this line of research by focusing on the effects of marine plant diversity on the diversity and biomass of associated animals (epifauna). Estuarine epifauna are dominated by abundant and productive generalist grazers, and represent a critical trophic link from primary producers to higher trophic levels
(Kikuchi 1974, Kitting et al. 1984, Fredette et al. 1990, Edgar \& Shaw 1995, Heck et al. 1995). Many previous studies have shown that, although habitat generalization is the rule, phytal epifaunal communities often differ significantly among plant species (Edgar 1983a, 1990b, Lewis 1984, 1987, Stoner 1985). Thus, we hypothesized that more diverse marine plant assemblages may support denser or more diverse epifaunal assemblages.

Our results, as well as experimental evidence from terrestrial ecosystems (Siemann 1998, Siemann et al. 1998, Symstad et al. 2000), suggest that the relationship between plant diversity and animal diversity is not strong. Plant diversity only accounted for about $13 \%$ of the variance in motile epifaunal diversity in our experiment, and plant species diversity did not significantly influence epifaunal species richness or evenness (Fig. 3). Similarly, plant diversity accounted for only about $12 \%$ of arthropod diversity in a terrestrial grassland (Siemann et al. 1998). In both Siemann's study (1998) and ours (Figs 2 \& 3), animal abundance was strongly affected by plant community attributes (e.g. plant productivity and surface area, respectively), thus indirectly increasing animal species diversity.

Although motile epifaunal assemblages were not strongly affected by changes in plant diversity in our experiment, plant species composition significantly affected epifaunal abundance and biomass (Table 7). It appears that either the increased habitat or microalgal food provided by the high surface area of seaweeds, and possibly other aspects of their complex structure, are the mechanisms supporting higher epifaunal abundance and biomass relative to seagrasses (Tables 4 to 6 , Fig. 2). Similarly, Stoner (1980) showed that epifauna respond more clearly to plant surface area than to plant biomass, although this pattern is not universal (Virnstein \& Howard 1987a,b). The significant interaction between plant species composition and plant surface area in our experiment (Table 7) suggests that epifauna are not responding solely to plant surface area. Our results agree in some respects with those of Siemann (1998), who found that both diversity and abundance of arthropods were greater in fertilized (i.e. more productive) plots, regardless of whether fertilization increased or decreased plant diversity. Thus, as also suggested by our results, Siemann's results indicate that animals respond more strongly to the amount of available resource than to the diversity of plants providing it.

The role of species diversity in ecosystem structure and function has received renewed interest of late (Schulze \& Mooney 1993, Schläpfer \& Schmid 1999, Tilman 1999), and experimental evidence generally has shown that attributes of particular species have greater impacts on ecosystem properties than plant 
diversity per se (Aarsen 1997, Huston 1997). Our results support this conclusion, and most specifically the 'idiosyncratic hypothesis' (Lawton 1994), i.e. animal community structure was more strongly influenced by the identity, rather than the number, of plant species in our experimental assemblages. For example, plant species diversity effects on epifaunal diversity and biomass were generally weak or nonexistent (Figs 2 \& 3), whereas after controlling for effects of plant surface area statistically, there were still significant effects of plant species composition on epifaunal abundance, biomass, and evenness (Table 7). Plant surface area also had higher MS and lower p-values than those for plant species composition in most of the ANCOVAs (Table 7), which could be construed to support the redundant species hypothesis, with a minimum critical level of 1 species. However, when put into context with multiple regression analyses, there are clear differences among plant taxa. For example, abundance of the red alga Gracilaria typically explained the highest proportion of the variance for any given model (Tables 4 to 6), and effects of the other plant species were either non-significant, significant but with low predictive power, or significant with nearly as much predictive power as Gracilaria.

Both empirical studies (Tilman \& Downing 1994, McGrady-Steed et al. 1997) and conceptual reviews (Lawton 1994, Vitousek \& Hooper 1994) suggest that relationships between species richness and community properties should be most evident in depauperate communities because the change in process rates tends to be greatest over the lower range of diversity. To test this relationship, most previous empirical studies focused on low-diversity subsets of naturally diverse assemblages. Our estuarine vegetation system, however, is naturally species-poor, and we found little evidence of the hypothesized relationship between plant diversity and ecosystem structure (in this case the diversity and biomass of motile plant-associated animals). Many species-poor ecosystems appear to be dominated by resource generalists (Costanza et al. 1993), such as the epifaunal species that we studied, and the addition of new species may be less likely to introduce new functional groups (sensu Steneck \& Watling 1982, Steneck \& Dethier 1994) than when assembling species from species-rich ecosystems. However, variation around the hypothesized relationship between species richness and functional process rates is also greatest at lower diversity (Naeem et al. 1996, Tilman et al. 1997), so spatially or temporally limited studies such as ours are less likely to capture the 'mean effect' of species diversity on associated patterns or processes (Tilman 1999). In general, our results indicate that communities are the sum of multiple interactions, such that knowledge of species' attributes will be critical to explaining and potentially predicting the effects of habitat degradation and species loss on ecosystem structure and function.

Acknowledgements. We thank Tripp Macdonald, Al Lombana, and the Virginia Institute of Marine Science (VIMS) Submersed Aquatic Vegetation and Crustacean Ecology groups for field help. Comments from Graham Edgar and 2 anonymous reviewers significantly improved the manuscript. This work is based on a thesis submitted in partial fulfillment of requirements for the Master of Science at the College of William and Mary (by J.D.P.). It was supported by grants from VIMS faculty (to J.D.P.) and NSF (OCE 95-21184 to J.E.D). This is contribution 2372 from the Virginia Institute of Marine Science, College of William and Mary.

\section{LITERATURE CITED}

Aarssen LW (1997) High productivity in grassland ecosystems: effected by species diversity or productive species? Oikos 80:183-184

Abele LG (1974) Species diversity of decapod crustaceans in marine habitats. Ecology 55:156-161

Bell JD, Westoby M (1986) Abundance of macrofauna in dense seagrass is due to habitat preference, not predation. Oecologia 68:205-209

Bologna PAX, Heck KL Jr (1999) Macrofaunal associations with seagrass epiphytes. Relative importance of trophic and structural characteristics. J Exp Mar Biol Ecol 242: 21-39

Boström C, Mattila J (1999) The relative importance of food and shelter for seagrass-associated invertebrates: a latitudinal comparison of habitat choice by isopod grazers. Oecologia 120:162-170

Carpenter RC (1986) Partitioning herbivory and its effects on coral reef algal communities. Ecol Monogr 56:345-363

Costanza R, Kemp WM, Boynton WR (1993) Predictability, scale, and biodiversity in coastal and estuarine ecosystems - implications for management. Ambio 22:88-96

Cruz-Rivera E, Hay ME (2000) The effects of diet mixing on consumer fitness: macroalgae, epiphytes, and animal matter as food for marine amphipods. Oecologia 123:252-264

Dean RL, Connell JH (1987a) Marine invertebrates in an algal succession. I. Variations in abundance and diversity with succession. J Exp Mar Biol Ecol 109:195-215

Dean RL, Connell JH (1987b) Marine invertebrates in an algal succession. II. Tests of hypotheses to explain changes in diversity with succession. J Exp Mar Biol Ecol 109: $217-247$

Dean RL, Connell JH (1987c) Marine invertebrates in an algal succession. III. Mechanisms linking habitat complexity with diversity. J Exp Mar Biol Ecol 109:249-273

Duffy JE, Harvilicz AM (2001) Species-specific impacts of grazing amphipods in an eelgrass-bed community. Mar Ecol Prog Ser 223:201-211

Duffy JE, Hay ME (1991) Food and shelter as determinants of food choice by an herbivorous marine amphipod. Ecology 72:1286-1298

Duffy JE, Hay ME (1994) Herbivore resistance to seaweed chemical defense: the roles of mobility and predation risk. Ecology 75:1304-1319

Duffy JE, MacDonald KS, Rhode JM, Parker JD (2001) Grazer diversity, functional redundancy, and productivity in seagrass beds: an experimental test. Ecology 82:2417-2434

Edgar GJ (1983a) The ecology of south-east Tasmanian phy- 
tal animal communities. I. Spatial organization on a local scale. J Exp Mar Biol Ecol 70:129-157

Edgar GJ (1983b) The ecology of south-east Tasmanian phytal animal communities. II. Seasonal change in plant and animal populations. J Exp Mar Biol Ecol 70:159-179

Edgar GJ (1983c) The ecology of south-east Tasmanian phytal animal communities. III. Patterns of species diversity. J Exp Mar Biol Ecol 70:181-203

Edgar GJ (1983d) The ecology of south-east Tasmanian phytal animal communities. IV. Factors affecting the distribution of ampithoid amphipods among algae. J Exp Mar Biol Ecol 70:205-225

Edgar GJ (1990a) The use of the size structure of benthic macrofaunal communities to estimate faunal biomass and secondary production. J Exp Mar Biol Ecol 137:195-214

Edgar GJ (1990b) The influence of plant structure on the species richness, biomass and secondary production of macrofaunal assemblages associated with Western Australian seagrass beds. J Exp Mar Biol Ecol 137:215-240

Edgar GJ (1991) Distribution patterns of mobile epifauna associated with rope fibre habitats within the Bathurst Harbour estuary, South-western Tasmania. Estuar Coast Shelf Sci 33:589-604

Edgar GJ (1992) Patterns of colonization of mobile epifauna in a Western Australian seagrass bed. J Exp Mar Biol Ecol 157:225-246

Edgar GJ, Aoki M (1993) Resource limitation and fish predation: their importance to mobile epifauna associated with Japanese Sargassum. Oecologia 95:122-133

Edgar GJ, Robertson AI (1992) The influence of seagrass structure on the distribution and abundance of mobile epifauna: pattern and process in a Western Australian Amphibolis bed. J Exp Mar Biol Ecol 160:13-31

Edgar GJ, Shaw C (1995) The production and trophic ecology of shallow-water fish assemblages in southern Australia. II. Diets of fishes and trophic relationships between fishes and benthos at Western Port, Victoria. J Exp Mar Biol Ecol 194:83-106

Fredette TJ, Diaz RJ (1986) Life history of Gammarus mucronatus Say (Amphipoda: Gammaridae) in warm temperate estuarine habitats, York River, Virginia. J Crustac Biol 6: $57-78$

Fredette TJ, Diaz RJ, van Montfrans J, Orth RJ (1990) Secondary production within a seagrass bed (Zostera marina and Ruppia maritima) in lower Chesapeake Bay. Estuaries 13:431-440

Hacker SD, Steneck RS (1990) Habitat architecture and the abundance and body-size-dependent habitat selection of a phytal amphipod. Ecology 71:2269-2285

Hall MO, Bell SS (1988) Response of small motile epifauna to complexity of epiphytic algae on seagrass blades. J Mar Res 46:613-630

Hay ME (1992) The role of seaweed chemical defenses in the evolution of feeding specialization and in the mediation of complex interactions. In: Paul VJ (ed) Ecological roles for marine natural products. Comstock Press, Ithaca, NY, p 93-118

Hay ME, Duffy JE, Pfister CA, Fenical W (1987) Chemical defenses against different marine herbivores: are amphipods insect equivalents? Ecology 68:1567-1580

Heck KL Jr, Wetstone GS (1977) Habitat complexity and invertebrate species richness and abundance in tropical seagrass meadows. J Biogeogr 4:135-142

Heck KL Jr, Able KW, Roman CT, Fahay MP (1995) Composition, abundance, biomass and production of macrofauna in a New England estuary: comparisons among eelgrass meadows and other nursery habitats. Estuaries 18:379-389
Hoegh-Guldberg O (1988) A method for determining the surface area of corals. Coral Reefs 7:113-116

Holmlund MB, Peterson CH, Hay ME (1990) Does algal morphology affect amphipod susceptibility to fish predation? J Exp Mar Biol Ecol 139:65-83

Holmquist JG (1997) Disturbance and gap formation in a marine benthic mosaic: influence of shifting macroalgal patches on seagrass structure and mobile invertebrates. Mar Ecol Prog Ser 158:121-130

Hooper DU (1998) The role of complementarity and competition in ecosystem responses to variation in plant diversity. Ecology 79:704-719

Howard RK (1985) Measurements of short-term turnover of epifauna within seagrass beds using an in situ staining method. Mar Ecol Prog Ser 22:163-168

Huston MA (1997) Hidden treatments in ecological experiments: re-evaluating the ecosystem function of biodiversity. Oecologia 110:449-460

Kikuchi T (1974) Japanese contributions on consumer ecology in eelgrass (Zostera marina L.) beds, with special reference to trophic relationships and resources in inshore fisheries. Aquaculture 4:145-160

Kitting CL, Fry B, Morgan MD (1984) Detection of inconspicuous epiphytic algae supporting food webs in seagrass meadows. Oecologia 62:145-149

Knowles LL, Bell SS (1998) The influence of habitat structure in faunal-habitat associations in a Tampa Bay seagrass system, Florida. Bull Mar Sci 62:781-794

Kohn AJ (1967) Environmental complexity and species diversity in the gastropod genus Conus on Indo-West Pacific reef platforms. Am Nat 101:251-259

Kotler BP, Brown JS (1988) Environmental heterogeneity and the coexistence of desert rodents. Annu Rev Ecol Syst 19: 281-307

Lande R (1996) Statistics and partitioning of species diversity, and similarity among multiple communities. Oikos 76:5-13

Lawton JH (1994) What do species do in ecosystems? Oikos 71:367-374

Leber KM (1985) The influence of predatory decapods, refuge, and microhabitat selection on seagrass communities. Ecology 66:1951-1964

Lewis FG III (1984) Distribution of macrobenthic crustaceans associated with Thalassia, Halodule and bare sand substrata. Mar Ecol Prog Ser 19:101-113

Lewis FG III (1987) Crustacean epifauna of seagrass and macroalgae in Apalachee Bay, Florida, USA. Mar Biol 94: 219-229

Loreau M (1998) Separating sampling and other effects in biodiversity experiments. Oikos 82:600-602

Lubchenco J, Gaines SD (1981) A unified approach to marine plant-herbivore interactions. I. Populations and communities. Annu Rev Ecol Syst 12:405-437

MacArthur RH, MacArthur JW (1961) On bird species diversity. Ecology 42:594-598

Marsh GA (1973) The Zostera epifaunal community in the York River, Virginia. Chesapeake Sci 14:87-97

McGrady-Steed J, Harris PM, Morin PJ (1997) Biodiversity regulates ecosystem predictability. Nature 390:162-165

Murdoch WW, Evans FC, Peterson CH (1972) Diversity and pattern in plants and insects. Ecology 53:819-829

Naeem S, Häkansson K Lawton JH, Crawley MJ, Thompson LJ (1996) Biodiversity and plant productivity in a model assemblage of plant species. Oikos 76:259-264

Olyslager NJ, Williams DD (1993) Microhabitat selection by the lotic amphipod Gammarus pseudolimnaeus Bousfield-mechanisms for evaluating local substrates and current suitability. Can J Zool 71:2401-2409 
Orth RJ (1992) A perspective on plant-animal interactions in seagrasses: physical and biological determinants influencing plant and animal abundance. In: John DM, Hawkins SJ, Price JH (eds) Plant-animal interactions in the marine benthos, Clarendon Press, Oxford, p 147-164

Orth RJ, Heck KL Jr, van Montfrans J (1984) Faunal communities in seagrass beds: a review of the influence of plant structure and prey characteristics on predator-prey relationships. Estuaries 7:339-350

Paine RT (1992) Food-web analysis through field measurement of per capita interaction strength. Nature 355:73-75

Parker JD (1998) Does plant diversity enhance animal diversity? An experimental approach. Master's thesis, College of William and Mary, Gloucester Point, VA

Pianka ER (1966) Convexity, desert lizards, and spatial heterogeneity. Ecology 47:1055-1059

Pianka ER (1967) On lizard species diversity: North American flatland deserts. Ecology 48:333-351

Schläpfer F, Schmid B (1999) Ecosystem effects of biodiversity: a classification of hypotheses and exploration of empirical results. Ecol Appl 9:893-912

Schneider FI, Mann KH (1991a) Species specific relationships of invertebrates to vegetation in a seagrass bed. I. Correlational studies. J Exp Mar Biol Ecol 145:101-117

Schneider FI, Mann KH (1991b) Species specific relationships of invertebrates to vegetation in a seagrass bed. II. Experiments on the importance of macrophyte shape, epiphyte cover and predation. J Exp Mar Biol Ecol 145:119-139

Schulze ED, Mooney HA (eds) (1993) Biodiversity and ecosystem function. Springer, New York

Siemann E (1998) Experimental tests of effects of plant productivity and diversity on grassland arthropod diversity. Ecology 79:2057-2070

Siemann E, Tilman D, Haarstad J, Ritchie M (1998) Experimental tests of the dependence of arthropod diversity on plant diversity. Am Nat 152:738-750

Smith B, Wilson JB (1996) A consumer's guide to evenness indices. Oikos 76:70-82

Sokal RR, Rohlf FJ (1995) Biometry: the principles and practice of statistics in biological research. WH Freeman and Company, New York

Southwood TRE, Brown VK, Reader PM (1979) The relationship of plant and insect diversities in succession. Biol J Linn Soc 12:327-348

Stachowicz JJ, Whitlach RB, Osman RW (1999) Species diversity and invasion resistance in a marine ecosystem. Science 286:1577-1579

Steneck RS, Dethier MN (1994) A functional group approach

Editorial responsibility: Kenneth Heck (Contributing Editor), Dauphin Island, Alabama, USA to the structure of algal-dominated communities. Oikos 69:476-498

Steneck RS, Watling L (1982) Feeding capabilities and limitation of herbivorous molluscs: a functional group approach. Mar Biol 68:299-319

Stoner AW (1980) Perception and choice of substratum by epifaunal amphipods associated with seagrasses. Mar Ecol Prog Ser 3:105-111

Stoner AW (1985) Penicillus capitatus: an algal island for macrocrustaceans. Mar Ecol Prog Ser 26:279-287

Stoner AW, Lewis FG III (1985) The influence of quantitative and qualitative aspects of habitat complexity in tropical sea-grass meadows. J Exp Mar Biol Ecol 94:19-40

Strong DR Jr, Lawton JH, Southwood R (1984) Insects on Plants. Blackwell Scientific Publications, Oxford

Symstad AJ, Siemann E, Haarstad J (2000) An experimental test of the effect of plant functional group diversity on arthropod diversity. Oikos 89:243-253

Taylor RB (1998) Short-term dynamics of a seaweed epifaunal assemblage. J Exp Mar Biol Ecol 227:67-82

Tilman D (1999) The ecological consequences of changes in biodiversity: a search for general principles. Ecology 80: 1455-1474

Tilman D, Downing JA (1994) Biodiversity and stability in grasslands. Nature 367:363-365

Tilman D, Lehman C, Knops J (1997) Plant diversity and ecosystem productivity: theoretical considerations. Proc Natl Acad Sci 94:1857-1861

Tonn WM, Magnuson JJ (1982) Patterns in the species composition and richness of fish assemblages in Northern Wisconsin lakes. Ecology 63:1149-1166

Virnstein RW, Curran MC (1986) Colonization of artificial seagrass versus time and distance from source. Mar Ecol Prog Ser 29:279-288

Virnstein RW, Howard RK (1987a) Motile epifauna of marine macrophytes in the Indian River Lagoon, Florida. I. Comparisons among 3 species of seagrasses from adjacent beds. Bull Mar Sci 41:1-12

Virnstein RW, Howard RK (1987b) Motile epifauna of marine macrophytes in the Indian River Lagoon, Florida. II. Comparisons between drift algae and 3 species of seagrasses. Bull Mar Sci 41:13-26

Vitousek PM, Hooper DU (1994) Biological diversity and terrestrial ecosystem biogeochemistry. In: Schulze ED, Mooney HA (eds) Biodiversity and ecosytem function. Springer, New York, p 3-14

Willson MF (1974) Avian community organization and habitat structure. Ecology 55:1017-1029

Submitted: February 11, 2000; Accepted: March 12, 2001

Proofs received from author(s): November 26, 2001 